\title{
Възможности и перспективи за прилагането на Инфлуцид в класическата профилактика на ОРВИ
}

\author{
С. О. Мокия-Сербина, Т. К. Мавропуло, \\ Н. В. Молочек, Н. В. Василенко, В. В. Чечель
}

\begin{abstract}
Резюме
Профилактичното назначаване на инфлуцид допринася за намаляване в срок от три месеца на честотата, продължителността и тежестта на ОРВИ, което е придружено от спад в цитотоксичната активност на NK-клетките, отговорни за антивирусната защита.

Оценката на ефективността на препарата инфлуцид спрямо причинителите на ОРВИ е проведена в открито плацебо контролирано клинично проучване за деца на 5-6-годишна възраст, посещаващи предучилищни детски заведения в епидемичния сезон януари-април 2009 г. (фиг. 1 и фиг. 2) Особено внимание се отделя за изследване влиянието на инфлуцид върху морфологичните показатели на NKклетките, които са показател за тяхната цитотоксична активност. В състояние на вирусна инфекция NK-клетките атакуват заразените клетки и активността им е повишена. Според изследването (фиг. 3) при профилактично прилагане на инфлуцид се отбелязва явен спад в цитотоксичността на NK-клетките, поради изразеното защитно действие на инфлуцид спрямо развитието на ОРВИ.

Анализът на поносимостта на инфлуцид в профилактичен режим на дозиране не показва никакви неблагоприятни и нежелани ефекти.
\end{abstract}

\section{Материали и метод на изследване}

Дизайн:

Открито плацебо-контролирано клинично наблюдение

$\begin{array}{ll}\text { Период: } & \text { януари - април } 2009 \\ \text { Пациенти: } & 60 \text { деца } \\ & \text { I група - инфлуцид } \\ & \text { II група - плацебо } \\ \text { Възраст: } & 5-6 \text { години } \\ \text { Продължител- } & 1 \text { месец } \\ \text { ност на профи- } & \\ \text { лактиката: } & \\ \text { Доза: } & 1 \text { табл. } 3 \text { пьти дневно } \\ \text { Контроли: } & \text { преди профилакти- } \\ & \text { ката, след } 1,2,3,4 \\ & \text { месеца }\end{array}$

Подборьт на децата в групите е на случаен принцип еднократно, при строго съблюдаване сроковете за провеждане на изследването и отчитайки условията за заразяване с вируси. Критериите за включване на пациенти в проучването са: деца без клинични признаци на ОРВИ; неваксинирани срещу грип; без сыпьтстващи тежки заболявания; разбиране на родителите за целта, задачите и хода на изследването, както и тяхното доброволно информирано съгласие. Критерии за изключване - използването на други антивирусни лекарства. Ако се развие ОРВИ, детето продължава да получава лекарството, но неговия режим се трансформира в терапевтична схема на дозиране. 
Оценката на профилактичната ефективност на препарата инфлуцид се извършва въз основа на следните показатели:

- брой деца, заболели от ОРВИ през периода на сезонно увеличена заболеваемост;

- брой деца, прекарали един епизод на ОРВИ;
- брой деца, с два или повече епизода на ОРВИ;

- период от първия прием на препарата до първя епизод на ОРВИ;

- срок за възникване на ОРВИ при децата през периода на наблюдение.

\section{Клинико-епидемиологични данни}

Заболеваемост от ОРВИ в епидемичния сезон при децата от Инфлуцид- и плацебо групите

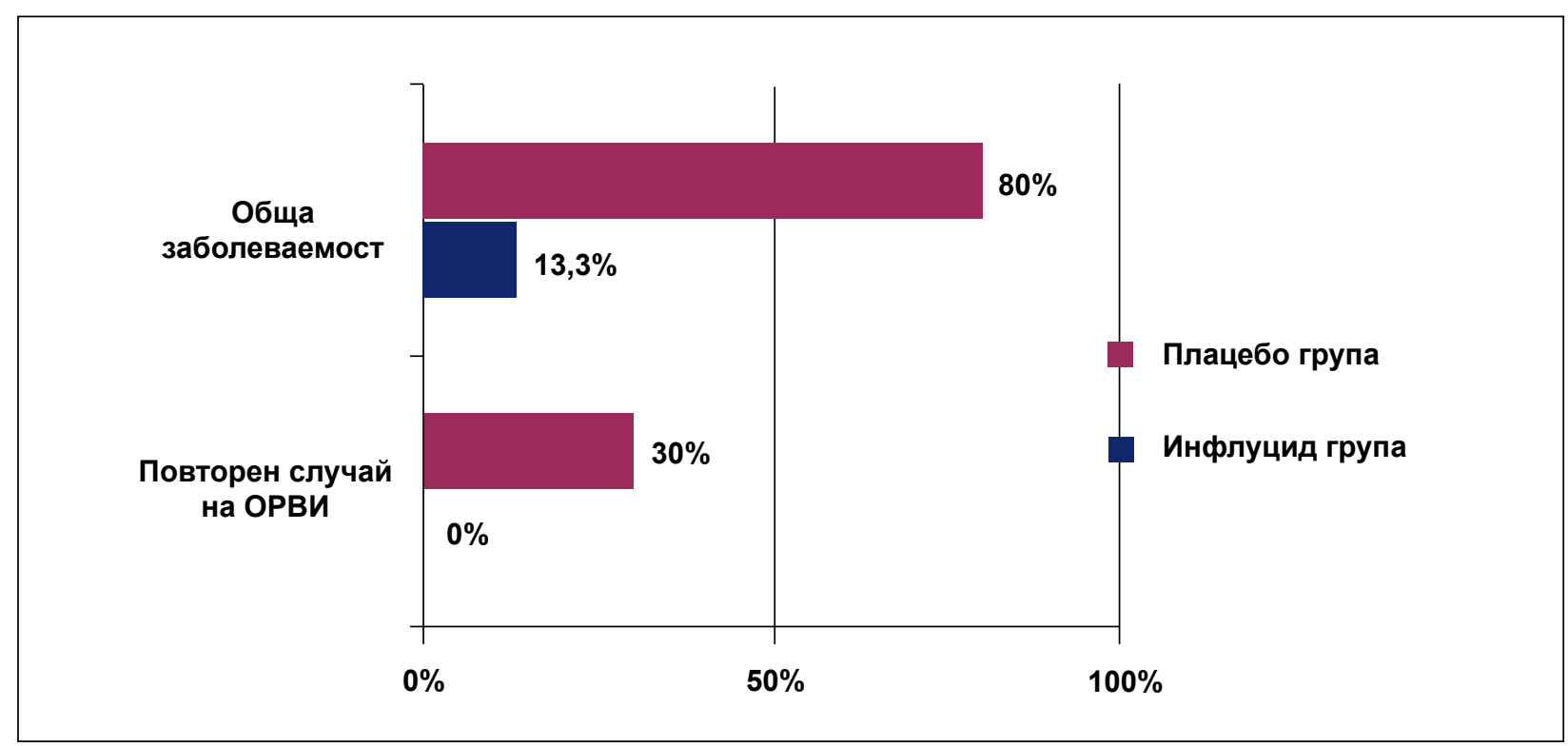

Профилактичното прилагане на инфлуцид предпазва срещу болестта 86,7\% от децата

Динамика на честотата на ОРВИ след прилагане на Инфлуцид в профилактична доза

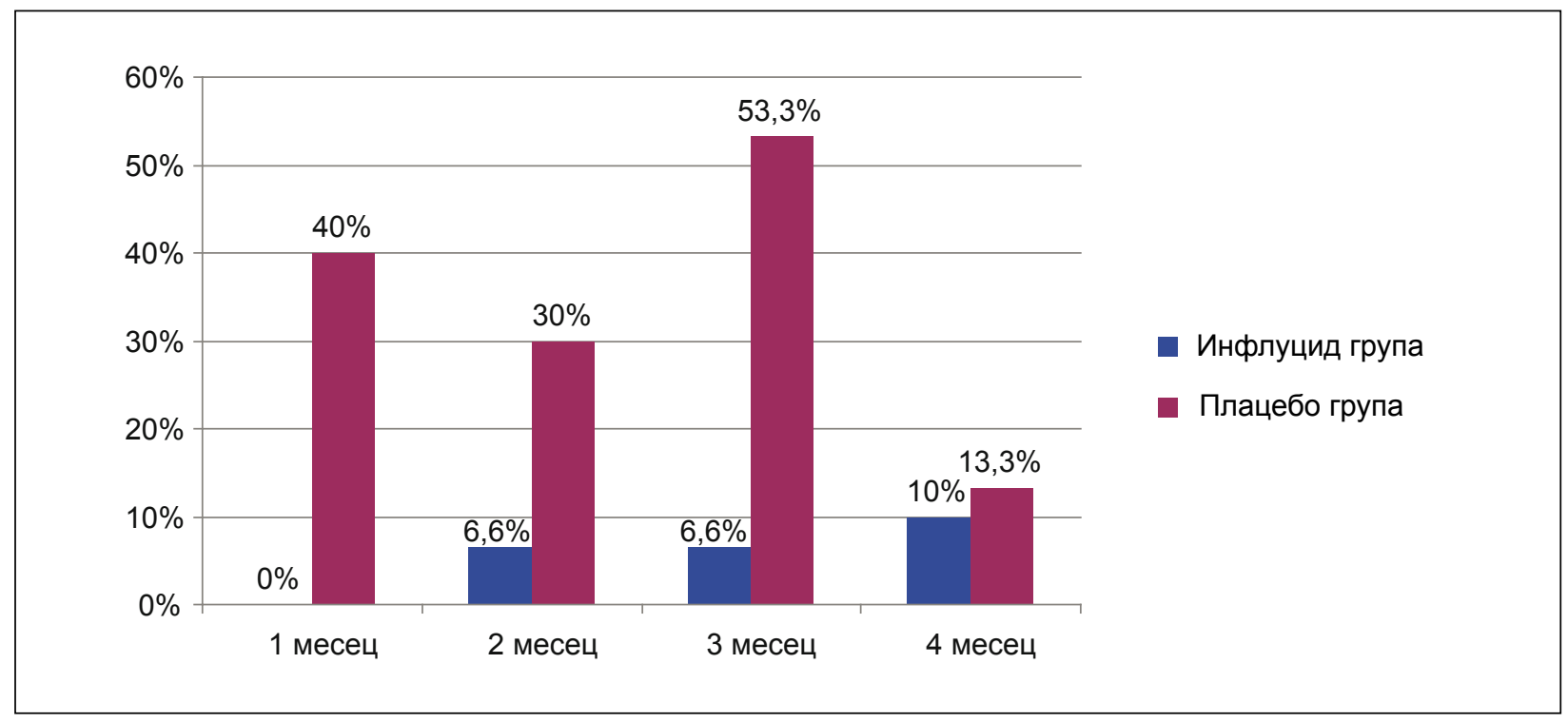


Значително по-ниска честота на ОРВИ при децата, получаващи инфлуцид в сравнение с плацебо-групата

\section{Имунологични данни}

Прилагането на инфлуцид в профилактичен режим оказва регулиращо влияние върху имунната система, което се изразява в промяна на функционалната активност на NK-клетките. Намалената цитотоксичност на NK-клетките се изразява в:

- намаляване броя и размера на гранулите;

- хомогенното им разположение в цитоплазмата;

- деструкция на гранули и тяхната замяна с вакуоли.

Имунологичното проучване е проведено в динамика: до началото и след 1 и 2 месеца от прие- мането на инфлуцид. При децата, със случаи на ОРВИ, втора имунологична проверка не е била правена.

Големите гранулирани лимфоцити са били преброени в кръвна намазка (на 100 лимфоцита) след оцветяване по метода на Романовски. Към тях са били причислени клетките с диаметър повече от 9 мкм, с крьгла или бобовидна форма на ядрото, широко обкръжени от цитоплазма, в която се намират не по-малко от три интензивно оцветени азурофилни гранули.

Определя се равномерното оцветяване на цитоплазмата, наличието на дегенеративни промени, характерна зърнистост, брой на гранулите в клетката, тяхното местоположение в цитоплазмата, естеството на зърнистост на гранулите и тяхното оцветяване.

Намален брой на гранулите в цитоплазмата на лимфоцитите

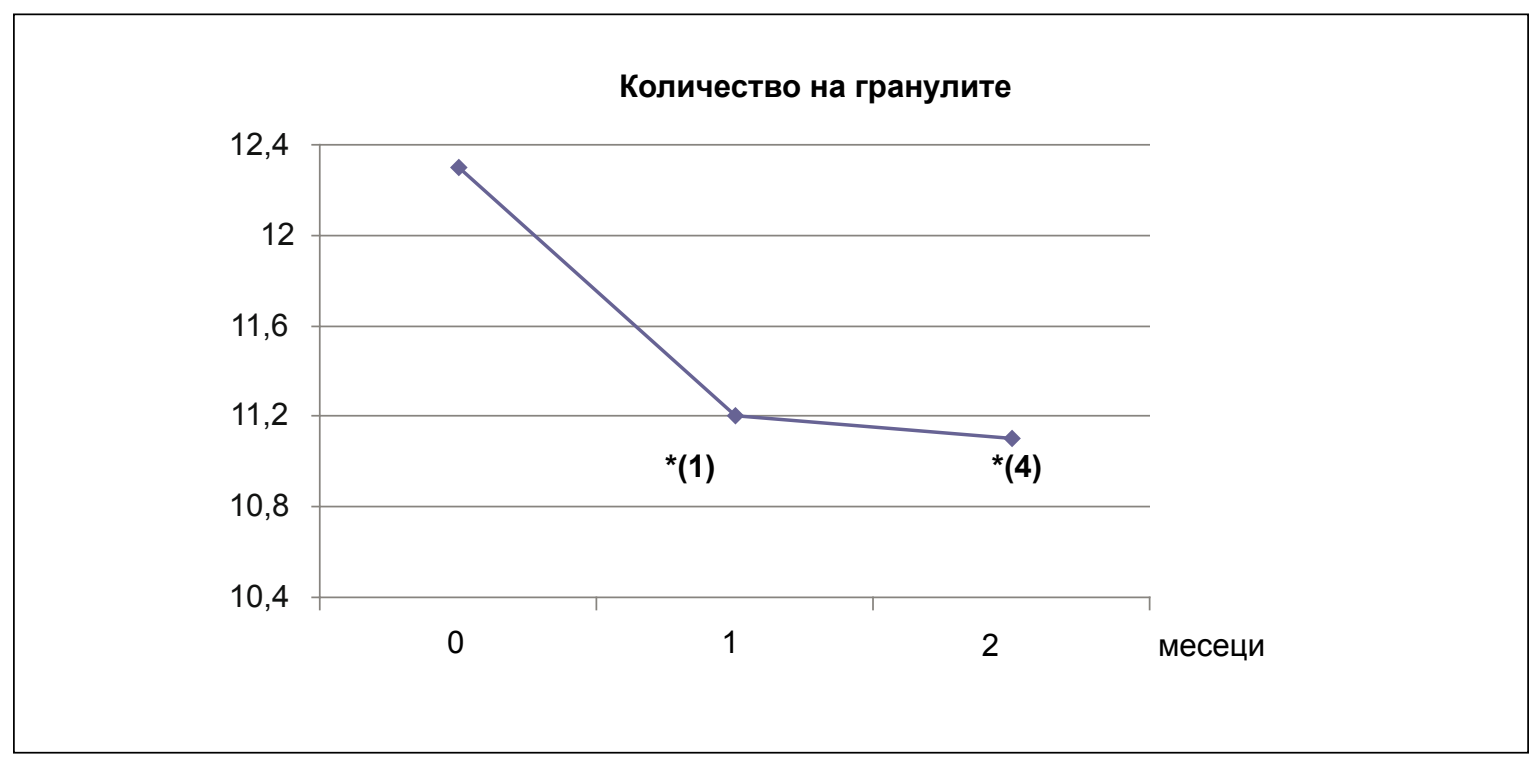

\section{Намален брой гранули -} ниска активност на NK-клетките

Резултатите от имунологичните изследвания на децата от основната група показват, че на фона на приемането на инфлуцид в профилактичен режим на дозиране и в продължение на следващия месец след края на приемането му количеството ГГЛ остава непроменено, но се променят морфологичните им характеристики.
Промяна във формата на ГГЛ - процентно намаляване на клетките с овална форма и увеличаване на тези с неправилна.

Промяната в характера на цитоплазмата и интензивността на оцветяването и: намалява процентното съдържание на ГГЛ, имащи еднороден характер и слабобазофилно оцветяване на цитоплазмата и нараства броя на лимфоцитите с интензивно базофилно оцветена цитоплазма и дегенеративни промени. 
Промени настьпват и в размера на ядрото: при приемането на инфлуцид се наблюдава статистически незначимо увеличение в диаметьра на ядрото, а през пьрвия месец след спиране на лекарството - значително намаляване на диаметъра на ядрото на ГГЛ.

От особен интерес е промяната в броя на гранулите в цитоплазмата на лимфоцитите. По време на приемане на препарата се наблюдава намаление на броя на гранулите в цитоплазмата на лимфоцитите, при спиране на лечението - незначимо. Значителни промени се наблюдават в разположението на гранулите в цитоплазмата на лимфоцитите. Увеличава се процента на ГГЛ с равномерно подреждането на гранулите и намалява броя на лимфоцитите, в които има струпвания на гранулите или се намират около клетъчната мембраната.
Анализът показа също така, значителни промени в интензивността на оцветяване на гранулите и в естеството на тяхната зърнистост. На фона на прием на инфлуцид се наблюдава значително увеличаване на процента на лимфоцитите с ниска интензивност на оцветяване на гранулите и намаление - на тези със средна интензивност. През следващия месец значително намалява броя на лимфоцитите със слабо оцветени гранули, но остава над началното ниво.

И така при приемане на инфлуцид се отбелязва явен спад в цитотоксичността на NK-клетките, който показва, че NK-клетки „почиват", поради което имунната система не е в състояние на напрежение и е в състояние да отговоря адекватно на променящите се условия.

\section{Изводи}

Профилактичното назначаване на инфлуцид допринася за намаляване в срок от три месеца на честотата, продължителността и тежестта на ОРВИ, което е придружено от спад в цитотоксичната активност на NK-клетките, отговорни за антивирусната защита.

По време на клинично наблюдение препаратът показва силно профилактично действие (86.7\%) спрямо ОРВИ в период на епидемично увеличена инфекциозна заболеваемост.

Анализът на поносимостта на инфлуцид в профилактичен режим на дозиране не показва никакви неблагоприятни и нежелани ефекти.

Може да се предположи, че прилагането на Инфлуцид в профилактичен режим оказва регулиращо влияние върху имунната система, което се изразява в промяната на функционалната активност на NK-клетките. Намалената цитотоксичност на NK-клетките на фона на приемане на инфлуцид показва, че вероятно NK-клетки „почиват“, поради което системата не е в състояние на напрежение и е в състояние да отговоря адекватно на променящите се условия. 